\title{
ANTI-DEPRESSANT EFFECT OF CEFTRIAXONE IN FORCED SWIMMING TEST AND IN TAIL SUSPENSION TEST IN MICE
}

\author{
AJOY BORAH ${ }^{1 *}$, BINITA SINGHA ${ }^{2}$, SWOPNA PHUKAN ${ }^{3}$ \\ 1Department of Pharmacology, Jorhat Medical College, Jorhat 785001, Assam, India, 2,3Department of Pharmacology, Gauhati Medical \\ College, Guwahati-32, Assam, India \\ Email: ajoyborah47@gmail.com
}

Received: 03 Aug 2016 Revised and Accepted: 09 Sep 2016

\begin{abstract}
Objective: Depression is a major psychiatric disorder affecting nearly 350 million people worldwide and imposes a substantial health burden on the society. Ceftriaxone has demonstrated neuroprotective effects in animals. It has also undergone trials as a treatment option for amyotrophic
\end{abstract} lateral sclerosis. This study was therefore undertaken to evaluate the antidepressant-like effect of ceftriaxone in mice.

Methods: Ceftriaxone was administered at three different doses $(0.130,0.195$ and $0.260 \mathrm{~g} / \mathrm{kg})$ to Swiss albino mice of either sex by intra peritoneal (i. p.) route. The period of immobility in control and drug-treated mice were recorded in forced swimming test (FST) and tail suspension test (TST). The antidepressant effect of ceftriaxone indicated by the decrease in duration of immobility was compared to that of fluoxetine ( $0.020 \mathrm{~g} / \mathrm{kg}$, i. p.).

Results: Ceftriaxone decreased the duration of immobility in mice. It showed a significant dose-dependent antidepressant effect. The antidepressant effect of $0.260 \mathrm{~g} / \mathrm{kg}$ of ceftriaxone was comparable to that of fluoxetine in the TST but not in the FST.

Conclusion: The results of the present study indicate antidepressant activity of Ceftriaxone. The study shows that ceftriaxone has additional action on the central nervous system other than neuroprotection. Ceftriaxone therapy in cases of encephalomeningitis and in various cases of hemorrhages in the brain can, therefore, prevent the development of depression in future.

Keywords: Forced swimming test, Tail suspension test, Penicillin, Depression, Amyotrophic lateral sclerosis

(C) 2016 The Authors. Published by Innovare Academic Sciences Pvt Ltd. This is an open access article under the CC BY license (http://creativecommons.org/licenses/by/4. 0/) DOI: http://dx.doi.org/10.22159/ijpps.2016v8i11.14466

\section{INTRODUCTION}

Depression is a common illness worldwide, which affects around 350 million people [1]. It has become a major psychiatric disorder and imposes a substantial health burden on the society [2, 3]. It presents with depressed mood, loss of interest or pleasure, decreased energy, feelings of guilt or low self-worth, disturbed sleep or appetite, and poor concentration. It can have coexisting anxiety and can also become chronic or recurrent [4]. Depression when long-lasting with moderate or severe intensity may become a serious health condition. It can cause the affected person to suffer greatly and function poorly at work, at school and in the family. At its worst, depression can lead to suicide. Over 800,000 people die due to suicide every year. Suicide is the second leading cause of death in 15-29 y olds [5]. There are three main kinds of classical antidepressants in clinical practice; the tricyclic antidepressants, selective serotonin reuptake inhibitors (SSRIs) and monoamine oxidase inhibitors (MAOIs) [6].

Ceftriaxone is a beta-lactam antibiotic belonging to the cephalosporin group ( $3^{\text {rd }}$ generation). It is an extensively used intravenous antibiotic for skin and soft tissue infections, enteric fever, complicated urinary tract infections; community acquired pneumonia, meningitis, abdominal sepsis and septicemia [7]. In recent times, some studies have demonstrated neuro-protective effects of beta-lactam antibiotics (notably ceftriaxone). These studies showed that ceftriaxone decreased glutamate-mediated excitetoxicity and reduced SOD (superoxide dismutase) induced neurotoxicity [8]. Ceftriaxone also underwent trials for the possible treatment of ALS (amyotrophic lateral sclerosis)[9-12]. Amyotrophic lateral sclerosis (ALS) is a neurodegenerative disorder caused by loss of cortical, brainstem and spinal motor neurons [9]. Based on these findings, this study was planned to evaluate whether or not ceftriaxone has other actions on the central nervous system. Therefore, ceftriaxone was evaluated for the presence of any antidepressant effect in forced swimming test and tail suspension test in mice.

\section{MATERIALS AND METHODS}

The study was carried out in the department of pharmacology, Gauhati Medical College.

\section{Ethical approval}

The protocol was approved by the Institutional Animal Ethics Committee of Gauhati Medical College and Hospital, Guwahati bearing approval no. MC/32/2013/9.

\section{Animals}

Swiss albino mice (weighing around 20-25 g) of either sex, from the animal house of the department of pharmacology, Gauhati Medical College were used in the present study. The animals were kept in the laboratory at $22 \pm 1{ }^{\circ} \mathrm{C}$ with free access to food and water. One animal was used only once in this study. All procedures in this study were performed in accordance with the Committee for the Purpose of Control and Supervision of Experiments on Animals (CPCSEA) guidelines.

\section{Chemicals and reagents}

1. Injection ceftriaxone (brand name monocef) procured from Central pharmacy, Gauhati Medical College

2. Capsule fluoxetine (brand name prozac) procured from Central pharmacy, Gauhati Medical College

\section{Grouping of animals}

The animals were grouped into 5 groups containing six animals in each group. The grouping of the animals for both the experiments was the same.

Group I: Normal Control Group [0.5 ml/kg normal saline intraperitoneal (i. p.)]

Group II: Standard Group (0.020g/kg fluoxetine i. p.) 
Group III: Ceftriaxone A Group ( $0.130 \mathrm{~g} / \mathrm{kg}$ ceftriaxone i. p.)

Group IV: Ceftriaxone B Group (0.195 g/kg ceftriaxone i. p.)

Group V: Ceftriaxone C Group ( $0.260 \mathrm{~g} / \mathrm{kg}$ ceftriaxone i. p.)

\section{Forced swimming test (FST)}

This test was carried out as described by Porsolt et al. [13] An open cylindrical container (diameter $0.10 \mathrm{~m}$ x height $0.25 \mathrm{~m}$ ) was filled with water up to a height of $0.15 \mathrm{~m}$. The water in the container was maintained at a temperature of $25 \pm 1^{\circ} \mathrm{C}$. Mice were forced to swim in this restricted space 30 min after the administration of the drugs. Mice cannot escape from this circumstance and this situation of inescapability induces a state of depression that is characterized by the behavior of immobility. A mouse was said to be immobile when it remained floating in the water with all the limbs motionless, making only those movements necessary to keep its head above water. The total duration of the experiment was 6 min. The duration of immobility in each mouse was recorded during the last 4 min of the 6 minute period $[14,15]$. Decrease in the duration of immobility is a measure of antidepressants activity.

\section{Tail suspension test (TST)}

This test was carried out as described by Steru et al. [16]. In this experiment, mice were suspended $0.50 \mathrm{~m}$ above the floor by adhesive tape placed approximately $0.01 \mathrm{~m}$ from the tip of the tail, after 0.30 min of the administration of the drugs. The duration of the experiment was 6 min. The duration of immobility in the mice was recorded. Antidepressant drugs decrease the duration of immobility.

\section{Determination of ceftriaxone dose for the study}

The dose of ceftriaxone in mice for this study was obtained by applying the conversion factor. The dose of ceftriaxone for skin, soft tissue and urinary infections in an adult patient is $1-2 \mathrm{~g} \mathrm{i}$. v. or $\mathrm{i}$. $\mathrm{m} /$ day [17]. Three human doses were considered for this study: $1 \mathrm{~g}$, $1.5 \mathrm{~g}, 2 \mathrm{~g}$. Multiplying them by the factor 0.0026 , [18] the corresponding doses in a $20 \mathrm{~g}$ mouse were obtained to be: $0.0026 \mathrm{~g}$, $0.0039 \mathrm{~g}, 0.0052 \mathrm{~g}$. Therefore, the doses of ceftriaxone in mice for this study were obtained to be $0.130 \mathrm{~g} / \mathrm{kg}, 0.195 \mathrm{~g} / \mathrm{kg}, 0.260 \mathrm{~g} / \mathrm{kg}$.

\section{Calculations}

1. Conversion of absolute human dose of ceftriaxone into absolute dose in mice (20 gm)

$1 \mathrm{~g} \mathrm{X} 0.0026=0.0026 \mathrm{~g}=0.0026 \mathrm{~g}$ for a $20 \mathrm{~g}$ mouse
$1.5 \mathrm{~g} \mathrm{X} 0.0026=0.0039 \mathrm{~g}=0.0039 \mathrm{~g}$ for a $20 \mathrm{~g}$ mouse.

$2 \mathrm{~g} \mathrm{X} 0.0026=0.0052 \mathrm{~g}=0.0052 \mathrm{~g}$ for a $20 \mathrm{~g}$ mouse

2. Conversion of absolute dose in mice into per kg body weight dose $0.0026 \mathrm{~g} / 20 \mathrm{~g}=0.130 \mathrm{~g} / 1000 \mathrm{~g}=0.130 \mathrm{~g} / \mathrm{kg}$

$0.0039 \mathrm{~g} / 20 \mathrm{~g}=0.195 \mathrm{~g} / 1000 \mathrm{~g}=0.195 \mathrm{~g} / \mathrm{kg}$

$0.0052 \mathrm{~g} / 20 \mathrm{~g}=0.260 \mathrm{~g} / 1000 \mathrm{~g}=0.260 \mathrm{~g} / \mathrm{kg}$

\section{Data analysis}

The data were analysed using the software graph pad prism 5.0. The data were expressed as mean \pm SEM (standard error of mean), difference between the experimental groups were statistically analyzed by one way analysis of variance (ANOVA) followed by the Bonferroni's test. $\mathrm{p}<0.05$ was considered to be significant.

\section{RESULTS}

The results of the study have been expressed in tables 1,2 and fig 1,2 .

In the forced swimming test, all the groups (II, III, IV, V) showed a significant reduction in the period of immobility when compared to the control group. Ceftriaxone showed dose-dependent reduction in the period of immobility. When compared with the standard antidepressant fluoxetine, the antidepressant effects of ceftriaxone were found to be significantly lower. (Refer table 1 and fig. 1).

\section{Period of Immobility in Forced swim test}

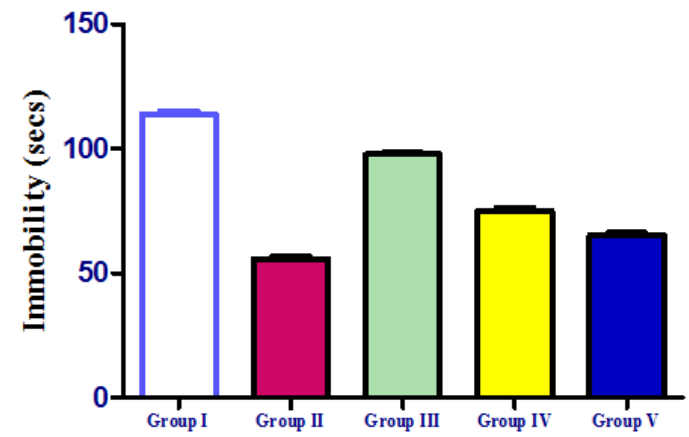

Fig. 1: Period of immobility in different groups in forced swim test

Table 1: Period of immobility in forced swimming test expressed as mean \pm sem

\begin{tabular}{llll}
\hline Groups & Drug & Dose & Period of immobility(seconds) \\
\hline Group I & Normal Saline & $0.5 \mathrm{ml} / \mathrm{kg}$ & $113.6667 \pm 1.3824$ \\
Group II & Fluoxetine & $0.020 \mathrm{~g} / \mathrm{kg}$ & $55.66667 \pm 0.8433$ \\
Group III & Ceftriaxone & $0.130 \mathrm{~g} / \mathrm{kg}$ & $97.66667 \pm 0.7149^{*, * *}$ \\
Group IV & Ceftriaxone & $0.195 \mathrm{~g} / \mathrm{kg}$ & $74.83333 \pm 1.352^{*, * *}$ \\
Group V & Ceftriaxone & $0.260 \mathrm{~g} / \mathrm{kg}$ & $65.16667 \pm 1.1377^{*}$, \\
\hline
\end{tabular}

${ }^{*}$. p value $<0.05$ when compared with group II, ${ }^{* * *}$. p value $<0.05$ when compared with group V

In the tail suspension test, all the groups (II, III, IV, V) showed a significant reduction in the period of immobility when compared to the control group. Ceftriaxone showed a dose-dependent reduction in the period of immobility. When compared with the standard antidepressant fluoxetine, the antidepressant effects of ceftriaxone were found to be significantly lower in group III $(0.130 \mathrm{~g} / \mathrm{kg})$ and group IV $(0.195 \mathrm{~g} / \mathrm{kg})$. The antidepressant effects of group IV $(0.260 \mathrm{~g} / \mathrm{kg}$ of ceftriaxone $)$ were found to be comparable with fluoxetine. (Refer table 2 and fig. 2)

Table 2: Period of immobility in tail suspension test expressed as tean \pm sem

\begin{tabular}{llll}
\hline Groups & Drugs & Dose & Period of immobility(secs) \\
\hline Group I & Normal Saline & $0.5 \mathrm{ml} / \mathrm{kg}$ & $96.5 \pm 1.118075$ \\
Group II & Fluoxetine & $0.020 \mathrm{~g} / \mathrm{kg}$ & $51.83333 \pm 1.778017$ \\
Group III & Ceftriaxone & $0.130 \mathrm{~g} / \mathrm{kg}$ & $81.66667 \pm 1.943722^{* * * *}$ \\
Group IV & Ceftriaxone & $0.195 \mathrm{~g} / \mathrm{kg}$ & $63.66667 \pm 1.563529^{* * * *}$ \\
Group V & Ceftriaxone & $0.260 \mathrm{~g} / \mathrm{kg}$ & $52.66667 \pm 1.960797$ \\
\hline
\end{tabular}

${ }^{*} \cdot$ p value $<0.05$ when compared with group II, ${ }^{* * *}$.p value $<0.05$ when compared with group V 
Period of Immobility in Tail suspension test

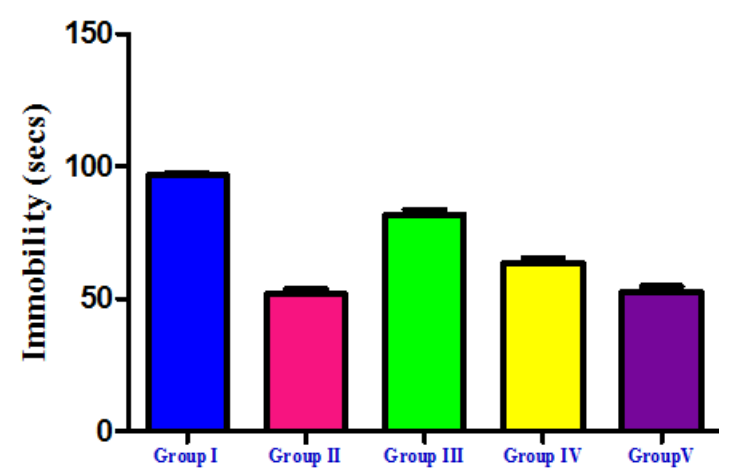

Fig. 2: Period of immobility in different groups in tail suspension test

\section{DISCUSSION}

Antidepressants act by increasing the availability of the monoamine transmitters; norepinephrine (NE), dopamine (DA), and 5hydroxytryptamine (5-HT). This is achieved by either preventing the metabolism of these neurotransmitters (inhibitors of the enzyme monoamine oxidase) or by blocking the transporter-mediated reuptake of the neurotransmitters (tricyclic antidepressants, selective serotonin reuptake inhibitors, selective norepinephrine reuptake inhibitors) [18]. Several other mechanisms have also been described to be responsible for the antidepressant effect. Antagonism of 5HT-2 receptor with serotonin reuptake blockade (nefazodone, trazodone) and alpha-2 receptor antagonism plus 5HT2 and 5HT-3 antagonism (mirtazapine) are some of these. The antidepressant effect of these drugs have also been attributed to the increase in the neurotrophic factors; brain-derived neurotrophic factor-BDNF, nerve growth factor, and neurotrophic factor-3[19]. The mechanism of antidepressant action of antipsychotics is due to 5HT-1A receptor agonism, 5HT-2A receptor antagonism, 5HT-2C receptor antagonism, $\alpha-2$ receptor antagonism, 5HT-7 receptor antagonism, 5HT-6 receptor antagonism [20]. H1 receptor antagonists like diphenhydramine have shown an antidepressant effect in animal models of depression [21, 22]. Tramadol (opioid agonist) has also shown an antidepressant effect in mice. It has been explained on its ability to modulate noradrenaline [23, 24], imidazoline receptors as well as opioid receptors [25] Antidepressant effect on the acute administration of tramadol is thought to be due to the inhibition of L-arginine-NO-C-AMP pathway [26] and modulation of $\mathrm{K}^{+}$channels [27]. Beta-lactam antibiotics (notably ceftriaxone), have been shown to prevent glutamateinduced neurotoxicity by increasing the expression and increasing the biochemical and functional activity of GLT1(glutamate transporter) in the brain [8] Ceftriaxone also showed neuroprotective effects in in vitro stroke model by a mechanism that was independent of GLT1 modulation [28]. Ceftriaxone also demonstrated neuroprotective potential in a rat model of traumatic brain injury by significantly reducing levels of the pro-inflammatory cytokines interleukin-1beta, interferon-gamma, and tumor necrosis factor-alpha and up-regulating GLT1 expression [29, 30]. Cognition enhancing effects were demonstrated by ceftriaxone in scopolamine induced amnesic mice models by inhibiting lipid peroxidation, augmenting antioxidant enzymes and decreasing acetyl-cholinesterases [31] Antidepressant action has also been attributed to modulation of various enzyme actions like indoleamine 2, 3-dioxygenase, nitric oxide synthase, monoamine oxidase, tryptophan hydroxylase, cyclooxygenase, serine/threonine kinase, histone acetyl transferases, histone deacetylases, matrix metalloproteinases, glutamine synthetase [32].

Other than its antimicrobial properties, ceftriaxone has numerous neurotropic effects. Although it has been established that the reduction in the duration of immobility time in the forced swimming and the tail suspension tests occur mainly due to the enhancement of central 5-HT and catecholamine neurotransmission [33], but it is difficult to comment on the exact mechanism of antidepressant-like action of ceftriaxone seen in this study. Further studies are needed to be conducted to gather in-depth information. The study has shown that ceftriaxone has additional action on the central nervous system other than neuroprotection. Long term ceftriaxone therapy in various cases of encephalomeningitis and in various cases of intracranial hemorrhages (cerebral hemorrhage, extradural hemorrhage, subdural hemorrhage) and other infectious like enteric fever can, therefore, prevent the development of depression in future.

\section{CONCLUSION}

The results of this study show that ceftriaxone has an antidepressant effect in mice.

\section{ACKNOWLEDGEMENT}

We take this opportunity to express our deep sense of respect and gratitude towards Prof. K. C. Saikia, principal-cum-chief superintendent, Gauhati Medical College and Hospital, for being kind enough to allow us to carry out this study and for providing the necessary infrastructure to complete this work. We would like to express our sincere gratitude towards Prof. (Mrs.) Mangala Lahkar, professor and head, department of pharmacology, GMCH for guiding us throughout, with her valuable suggestions. We sincerely acknowledge my co-PGT's, Dr. Arijit Dutta, Dr. Biswajit Aich, Dr. Atifa Ahmed, Dr. Bidyut Banerjee, Dr. Chimi Handique, Dr. Karishma Adhikari, Dr. Syed Adam Mousum for their sincere co-operation and help and providing us with the zeal and enthusiasm during the course of our study.

\section{CONFLICT OF INTERESTS}

\section{Declared none}

\section{REFERENCES}

1. http://www.who.int/mediacentre/factsheets/fs369/en/. [Last accessed on 02 Jul 2016].

2. Nemeroff CB. The burden of severe depression: a review of diagnostic challenges and treatment alternatives. J Psychiatr Res 2007;41:189-206.

3. Lai JS. A systematic review and meta-analysis of dietary patterns and depression in community-dwelling adults. Am J Clin Nut 2014;99:181-97.

4. Thachil A, Mohan R, Bhugra D. The evidence base of complementary and alternative therapies in depression. J Affective Disord 2007;97:23-35.

5. http://www.who.int/mental_health/prevention/suicide/suicid eprevent/en/. [Last accessed on 02 Jul 2016].

6. Nash J, Nutt D. Antidepressants. Psychiatry 2007;6:289-94.

7. Sharma HL, Sharma KK. Principles of pharmacology. Penicillin, Cephalosporins, and other Beta-Lactam Antibiotics. Paras Medical Publishers. $2^{\text {nd }}$ edition; 2013. p. 728.

8. Rothstein JD, Patel S, Regan MR, Haenggeli C, Huang YH, Bergles DE, et al. Beta-lactam antibiotics offer neuroprotection by increasing glutamate transporter expression. Nature 2005;433:73-7.

9. Yacila G, Sari Y. Potential therapeutic drugs and methods for the treatment of amyotrophic lateral sclerosis. Curr Med Chem 2014;21:3583-93.

10. Berry JD, Shefner JM, Conwit R, Schoenfeld D, Keroack M, Felsenstein D, et al. Design and initial results of a multi-phase randomized trial of ceftriaxone in amyotrophic lateral sclerosis. PLOS One 2013;8:e61177.

11. Cudkowicz M, Shefner J. NEALS consortium STAGE 3 clinical trial of ceftriaxone in subjects with ALS. Neurology 2013;80:S36.001.

12. Cudkowicz ME, Titus S, Kearney M, Yu H, Sherman A, Schoenfeld D, et al. Safety and efficacy of ceftriaxone for amyotrophic lateral sclerosis: a multi-stage, randomized, double-blind, placebocontrolled trial. Lancet Neurol 2014;13:1083-91.

13. Porsolt RD, Bertin A, Jalfre M. Behavioral despair in mice: a primary screening test for antidepressants. Arch Int Pharmacodyn Ther 1977;229:327-36.

14. Zomkowski A, Oscar A, Lin J, Santos A, Calixto J, Rodrigues A. Evidence for serotonin receptor subtypes involvement in agmatine antidepressant-like effect in the mouse forced swimming test. Brain Res 2004;1023:253-63. 
15. Jawaid T, Kamal M, Imam SA. Antidepressant activity of methanolic extract of verbena officinalis linn. plant in mice. Asian J Pharm Clin Res 2015;8:308-10.

16. Steru L, Chermat R, Thierry B, Simon P. The tail suspension test: a new method for screening antidepressants in mice. Psychopharmacology 1985;85:367-70.

17. Tripathi KD. Essentials of medical pharmacology. $7^{\text {th }}$ edition. Jaypee Brothers Medical Publishers (P) Ltd; 2013. p. 728.

18. Medhi B, Prakash A. Practical manual of experimental and clinical pharmacology. First Edition. Jaypee Brothers Medical Publishers (P) Ltd; 2010. p. 24-5.

19. Katzung BG, Master SB, Trevor AJ. Basic and clinical pharmacology. 12th edition. McGraw-Hill Companies, California; 2012. p. 521-37.

20. Šagud M, Peleš AM, Begić D, Ćusa BV, Kramarić M, Živković M, et al. Antipsychotics as antidepressants: What is the mechanism? Psychiatria Danubina 2011;23:302-7.

21. Khanwelkar CC, Gokhale DV, Sontakke AV, Patil SS. Effects of $\mathrm{H} 1-$ receptor antagonists in antidepressant tests in rats. $\mathrm{Al}$ Ameen J Med Sci 2008;1:84-92.

22. Taqa GA. Evaluation of the antidepressant activity of diphenhydramine in mice. Innovare J Med Sci 2013;1:15-8.

23. Mukta NC, Manjunath M, Gopalkrishna HN, Gokul P. Evaluation of the role of the noradrenergic system in the antidepressant activity of Tramadol using tail suspension test in Albino mice. J Pharmacol Pharmacother 2011;2:281-2.

24. Manjunath M, Mukta NC, Gopalkrishna HN, Gokul P. Evaluation of the role of the noradrenergic system in the antidepressant activity of tramadol using forced swim test in Albino mice. Pharmacologyonline 2011;3:243-50.

25. Faron GA, Kusminder M, Inan SY, Siwanowicz J, Piwowarczyck $\mathrm{T}$, Dziedzicka WM, et al. Long-term exposure of rats to Tramadol alters brain dopamine and alpha 1 adrenoceptor function that may be related to antidepressant potency. Eur J Pharmacol 2004;501:103-10.

26. Jesse CR, Bortolatto CF, Savegnago L, Rocha JBT, Nogueira CW. Involvement of L-arginine-nitric oxide-cyclic guanosine monophosphate pathway in the antidepressant-like effect of tramadol in the rat forced swimming test. Prog NeuroPsychopharmacol Biol Psychiatry 2008;32:1838-43.

27. Jesse CR, Wilhelm EA, Barbosa NBV, Nogueira CW. Involvement of different types of potassium channels in the antidepressantlike effect of tramadol in the mouse forced swimming test. Eur J Pharmacol 2009;613:74-8.

28. Lipski J, Wan CK, Bai J. Neuroprotective potential of ceftriaxone in in vitro models of stroke. Neuroscience 2007;146:617-29.

29. Wei J, Pan X, Pei Z, Wang W, Qiu W, Shi Z, et al. The beta-lactam antibiotic, ceftriaxone, provides neuroprotective potential via antiexcitotoxicity and anti-inflammation response in a rat model of traumatic brain injury. J Trauma Acute Care Surg 2012;73:654-60.

30. Cui C, Cui Y, Gao J, Sun L, Wang Y, Wang K, et al. Neuroprotective effect of ceftriaxone in a rat model of traumatic brain injury. J Neurol Sci 2014;35:695-700.

31. Akina S, Thati M, Puchchakayala G. Neuroprotective effect of ceftriaxone and selegiline on scopolamine-induced cognitive impairment in mice. Adv Biol Res 2013;7:266-75.

32. Walia V. Role of enzymes in the pathogenesis of depression. J Crit Rev 2016;3:11-6.

33. Borsini F, Meli A. Is the forced swimming test a suitable model for revealing antidepressant activity? Psychopharmacology (Berl) 1988;94:147-60.

\section{How to cite this article}

- $\quad$ Ajoy Borah, Binita Singha, Swopna Phukan. Antidepressant effect of ceftriaxone in forced swimming test and in tail suspension test in mice. Int J Pharm Pharm Sci 2016;8(11):191-194. 